\title{
Agronomic Strategies for Vegetative Propagation of Pterocarpus Mildbraedii
}

Canadian Journal of Agriculture and Crops

Vol. 7, No. 1, 1-10, 2022

e-ISSN: 2518-6655

check for
updates

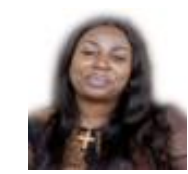

( Corresponding Author)

Okoli, N. A. ${ }^{1}$

Obasi, A. Z. ${ }^{2}$

Offorji, E. ${ }^{3}$

'Department of Crop Science and Horticulture, Nnamdi Azikiwe University, Awka, Nigeria. Email:na.okoli@,unizik.edu.ng

${ }^{2,3}$ Department of Crop Science and Technology, Federal University of Technology, Owerri, Nigeria. Email:amderealangel@yahoo.com ${ }^{s}$ Email: okolinamartin@gmail.com

Pterocarpus mildbraedii is faced with the problem of extinction caused mainly by deforestation and urbanization. This study was carried out to determine ways to enhance root development and domestication of Pterocarpus mildbraedii in southeastern Nigeria. The first experiment was done to determine the effect of nursery media and stem cutting length on sprouting and growth of Pterocarpus mildbraedii. Treatments consisted of three nursery media; (Standard nursery media, top soil and sawdust) and four stem cutting lengths; (5, 10, 15 and $20 \mathrm{~cm})$. The experiment was a $3 \mathrm{x} 4$ factorial arrangement laid out in Complete Randomized Design. In the second experiment, treatments consisted of five (5) hours of priming (0,12, 24, 36 and 48 hours) in coconut water arranged in Complete Randomized Design. Results from the first experiment showed that nursery media did not significantly $(\mathrm{P} \leq 0.05)$ affect sprouting and growth of Pterocarpus mildbraedii seedlings. However, stem cutting length significantly affected sprouting and growth of the shoots. Stem cuttings of 15 and $20 \mathrm{~cm}$ length sprouted earliest and had vigorous growth than cuttings of 5 and $10 \mathrm{~cm}$ lengths. However, shoots wilted one month after sprouting. Results from second experiment showed that stem cutting primed in coconut water for 24 hours significantly produced highest no of roots (12.00), longest root $(9 \mathrm{~cm})$ and had highest fresh biomass $(11.55 \mathrm{~g})$ while control had no roots and least fresh biomass $(3.02 \mathrm{~g})$. The results showed the possibility of vegetative propagation of Pterocarpus mildbraedii and domestication in southeastern Nigeria.

Keywords: Priming, Stem cutting length, Coconut water, Domestication, Pterocarpus mildbraedii.

DOI: $10.55284 /$ cjac.v7i1.601

Citation $\mid$ Okoli, N. A.; Obasi, A. Z.; Offorji, E. (2022). Agronomic Strategies for Vegetative Propagation of Pterocarpus mildbraedii.

Canadian Journal of Agriculture and Crops, 7(1): 1-10.

Copyright: This work is licensed under a Creative Commons Attribution 3.0 License

Funding: This study received no specific financial support.

Competing Interests: The authors declare that they have no competing interests.

History: Received: 12 October 2021 / Revised: 5 January 2022/ Accepted: 21 January 2022/ Published: 7 February 2022

Publisher: Online Science Publishing 


\section{Highlights of this paper}

- Priming in coconut was used to initiate rooting in Pterocarpus mildbraedii sprouts after the sprouts failed to develop roots.

- The experimental result showed the effectiveness of coconut water as plant growth hormone and demonstrated that coconut water is a cheap replacement of chemical growth hormones such as auxins.

\section{INTRODUCTION}

Pterocarpus mildbraedii is a tree vegetable of papilionaceae family. Pterocarpus mildbraedii is an indigenous tree of West African origin and one of the neglected plants of horticultural importance in a traditional farming systems of tropical Africa [1]. The leaves of Pterocarpus mildbraedii are used as vegetables in Nigeria in both rainy and dry seasons. The trees are used to provide shade in cocoa plantations in Ghana and the woods are used to make mortars in Tanzania [2].

In Southeastern Nigeria, vegetables are abundantly available during the rainy season while during the dry season; there are a lot of scarcities of vegetables because of lack of irrigation facilities [3]. Rural dwellers rely mostly on indigenous tree vegetables such as Pterocarpus mildbraedii and Vitex donia for daily consumption when other vegetables become scarce and very expensive during the dry season [4]. However, Pterocarpus mildbraedii, an all year round vegetable is threatened by extinction caused by urbanization, indiscriminate felling of trees, and development of new housing schemes that resulted in large scale of destruction of the natural forests that are rich sources of plant used as food [5]. Pterocarpus mildbraedii can be described as one of the lost crops of Africa because farmers harvest them mostly in the rural areas without much effort to cultivate new ones. Therefore, preservation of endangered species of Pterocarpus mildbraedii to avoid total extinction is a priority and can be achieved through massive development of seedlings for tree planting. Pterocarpus mildbraedii is propagated vegetatively using stem cuttings of matured wood [6]. Pterocarpus mildbraedii cuttings have poor rooting ability. In order to prevent poor root development and subsequently wilting of the shoots one month after sprouting in the nursery, there is need for pretreatment of Pterocarpus mildbraedii stem cuttings to improve rooting and growth in Pterocarpus mildbraedii. Pretreatments such as priming in water [7], coconut water [8], and use of chemical hormones [9] have been reported to aid rooting in stem cuttings of Pterocarpus mildbraedii.

Coconut water is rich in sugars, proteins, amino acids, salts, nitrogen, potassium, growth substances and enzymes. Coconut water is also able to encourage callus induction and serves as a buffer solution because it contains urea diphenil and cytokines that affect cell division activity [10]. Besides being rich in minerals, coconut water also contains various vitamins and natural hormones, i.e. auxin and cytokinin as coconut embryonic cell division supporter [10]. Priming of stem cuttings and seeds in water, coconut water and hormones have been found to be effective in inducing rooting and growth [7]. Pre-germination treatment of T. tetraptera seeds using coconut water significantly improved seedling growth and development [8].

However, there is paucity of information on the use of coconut water to induce rooting in Pterocarpus mildbraedii and this could be the reason for extinction of Pterocarpus mildbraedii in southeastern Nigeria.

Therefore, the objective of this research work is to determine the effect of hours of priming of Pterocarpus mildbraedi stem cutting in coconut water on root and shoot development.

\section{MATERIALS AND METHODS}

The field experiments were carried out at the Teaching and Research Farm, Federal University of Technology, Owerri, Imo State (latitude $5027^{\prime} \mathrm{N}$ and 70 o2' E) during the early cropping season. 
2.1. Experiment One: Effect of Stem Cutting Length and Nursery Media on Sprouting And Growth of Pterocarpus Mildbraedii

The treatments consisted of 2 factors namely; four cutting lengths (5.0, 10.0, 15.0 and 20.0cm) and three nursery media (sawdust, topsoil and standard nursery mixture). Standard nursery mixture was gotten from the mixture of top soil, poultry manure and river sand in the ratio of 3:2:1. The experiment was a $4 \times 3$ factorial laid out in Complete Randomized Design (CRD) with three replications as reported in Okoli, et al. [6].

\subsection{Experiment Two: Effect of Hours of Priming on Pterocarpus Mildbraedii Stem Cuttings in Coconut Water}

The treatments consisted of five (5) hours of priming (0,12, 24, 36 and 48 hours). Zero priming was the control. Stem cutting of $20 \mathrm{~cm}$ length was used in the experiment. The experimental design was Complete Randomized Design (CRD) with three replications.

\subsection{Nursery Establishment}

The nursery site was cleared using machete and 13 litre perforated plastic buckets filled with standard nursery mixture. Pterocarpus mildbraedii stems were collected from Mbaise, Imo State, Nigeria. In the experiment one, six stem cuttings of the specified length were planted in perforated bucket filled with different nursery media. In the second experiment, standard nursery media was used in the propagation of the stem cutting of $20 \mathrm{~cm}$ length. Coconut water were gotten from matured coconut fruits in the Faculty Genetic Resource Unit.

\subsection{Characterization of Poultry Manure, Sawdust and Top Soil}

Samples of the cured poultry manure, sawdust and soil were collected randomly from the bulk, air dried in the laboratory under room temperature for 14 days. Soil $\mathrm{pH}$ was analyzed by the use of $\mathrm{pH}$ meter [11], organic carbon was determined by Nelson and Sommers, 1982, organic matter values were obtained by multiplying total carbon with 1.724 (Van Bemmelen's correlation factor) [12], available phosphorus was determined according to the procedure of Olsen and Sommers [13], total nitrogen was by microkjeldahl digestion technique [14], calcium and magnesium by Versenate titration method and potassium by flame photometer method. Poultry manure and palm bunch ash were analyzed for their nutrient contents ( $\mathrm{pH}, \mathrm{N}, \mathrm{P}, \mathrm{K}, \mathrm{C}, \mathrm{Ca}, \mathrm{Mg}$ and $\mathrm{Na}$ ) using the same procedures as for the soil analysis. The particle size fractions were determined by the hydrometer method of Bouyoucos [15] using sodium hexa metaphosphate as a dispersant.

\subsection{Data Analysis}

Data on growth parameters (days to first sprouting, days to $50 \%$ sprouting, shoot height, number of leaves, number of roots and dry matter) were collected in the first and second experiments and the data were subjected to analysis of variance using Genstat [16]. Least significant difference (LSD) at 5\% level of probability was used to separate the means.

\section{RESULTS AND DISCUSSION}

\subsection{Physical and Chemical Properties of Nursery Media}

Water holding capacity was highest in standard nursery mixture (35.19\%) followed by topsoil (30.79 \%) while sawdust (28.33\%) had least water holding capacity Table 1. Sawdust had highest organic matter content (34.74\%) followed by standard nursery media $(3.71 \%)$ while topsoil had the least organic matter $(2.30 \%)$. 
Table 1. Properties of media used for raising Pterocarpus mildbraedii in the nursery.

\begin{tabular}{lccc}
\hline & Standard Nursery Media & Sawdust & Topsoil \\
\hline Water holding capacity (\%) & 47.17 & 30.79 & 28.33 \\
\hline Organic matter (\%) & 3.71 & 2.30 & 34.74 \\
\hline Organic carbon (\%) & 2.14 & 1.26 & 20.15 \\
\hline Total nitrogen (\%) & 0.07 & 0.02 & 0.14 \\
\hline Potassium (\%) & 0.09 & 0.04 & 0.24 \\
\hline Phosphorus (\%) & 0.02 & 0.01 & 0.09 \\
\hline pH $\left(\mathrm{H}_{2} \mathrm{O}\right)$ & 6.59 & 5.60 & 6.70 \\
\hline
\end{tabular}

3.2. Results of Experiment One: Effect of Stem Cutting Length and Nursery Media on Sprouting and Growth of Pterocarpus Mildbraedii

\subsubsection{Days to First Sprouting}

Days to first sprouting was not significantly $(\mathrm{p} \leq 0.05)$ affected by stem cutting length, nursery media and stem cutting length and nursery media interaction (Figure 1). On mean basis, stem cutting of $20 \mathrm{~cm}$ length (8 days) sprout earliest while stem cutting of $5 \mathrm{~cm}$ length (9 days) sprouted late. Stem cutting propagated in standard nursery media, sawdust and topsoil sprouted within 8 days. Stem cutting of 15 and $20 \mathrm{~cm}$ lengths raised in topsoil sprouted earliest (7 days) while stem cutting of $5 \mathrm{~cm}$ length sprouted late (10 days).

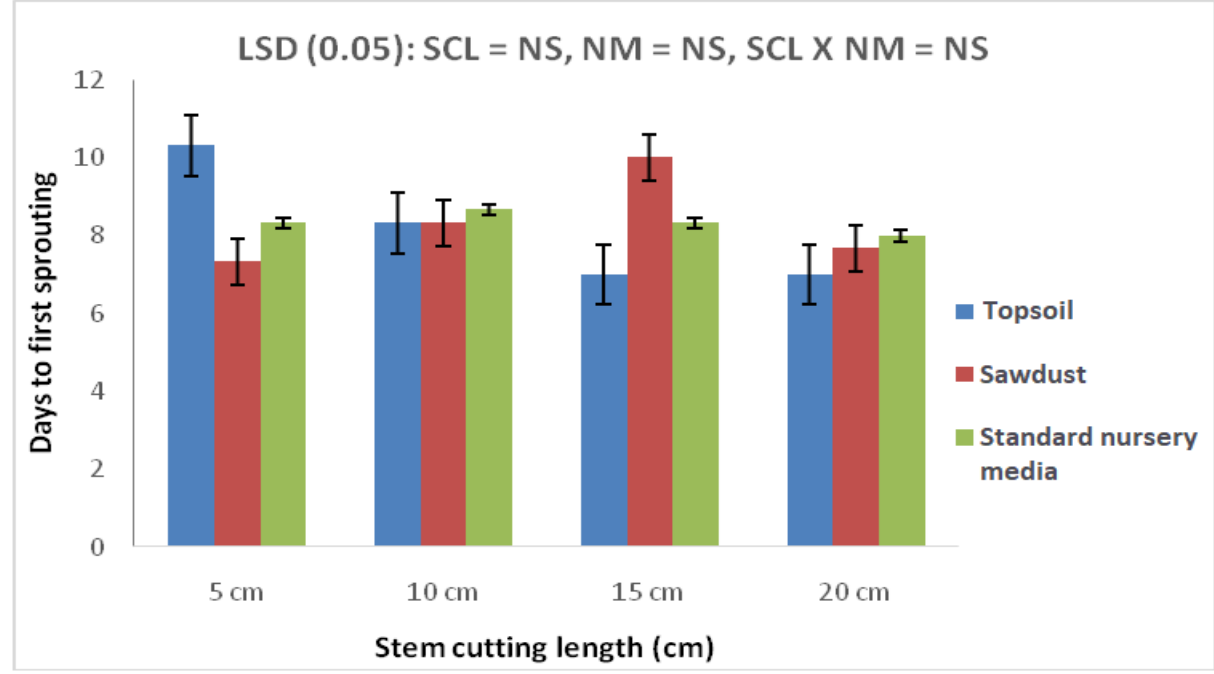

Figure 1. Effect of stem cutting length and nursery media on days to first sprouting. Note: $\mathrm{SCL}=$ Stem cutting length, $\mathrm{NM}=$ Nursery media, $\mathrm{NS}=$ Non significant

\subsubsection{Days to $50 \%$ Sprouting}

Days to $50 \%$ sprouting was significantly ( $\leq$ 0.05) affected by stem cutting length (Figure 2). Stem cutting lengths of 10,15 and $20 \mathrm{~cm}$ achieved $50 \%$ sprouting in 10 days while stem cutting length of $5 \mathrm{~cm}$ had $50 \%$ sprouting in 16 days. On mean value basis, standard nursery media and sawdust had 50 \% sprouting in 12 days while topsoil had $50 \%$ sprouting in 11 days. Stem cutting of $10 \mathrm{~cm}$ length raised in sawdust had $50 \%$ sprouting in 9 days while stem cutting of $5 \mathrm{~cm}$ length raised in sawdust had $50 \%$ sprouting in 18 days.

\subsubsection{Number of Leaves}

Number of leaves was significantly ( $\mathrm{p} \leq 0.05)$ affected by stem cutting length (Figure 3). Number of leaves was highest in stem cutting of $20 \mathrm{~cm}$ length (16.00), followed by stem cutting of $15 \mathrm{~cm}$ length (15.10) while stem cutting of $5 \mathrm{~cm}$ length produced lowest number of leaves (4.10). There was no significant difference between number of 
leaves produced by stem cutting of $20 \mathrm{~cm}$ length (16.00) and stem cutting of $15 \mathrm{~cm}$ length (15.10). On mean value basis, number of leaves was highest in standard nursery media (11.70) and least in topsoil (11.20). Stem cutting of 5 $\mathrm{cm}$ length raised in sawdust produced least number of leaves (2.00) while stem cutting of $20 \mathrm{~cm}$ length raised in standard nursery media produce highest number of leaves (21.10).

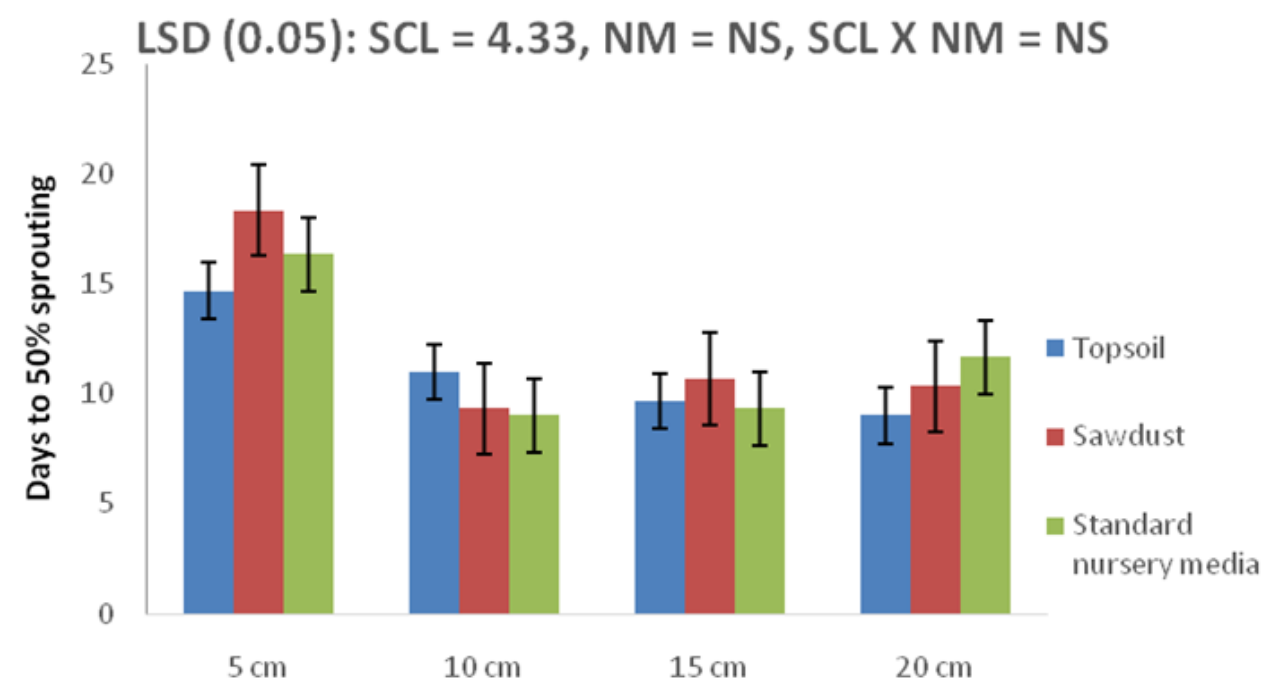

Stem cutting length $(\mathrm{cm})$

Figure 2. Effect of stem cutting length and nursery media on days to days to $50 \%$ sprouting: Note: $\mathrm{SCL}=$ Stem cutting length, $\mathrm{NM}=$ Nursery media, NS = Non significant.

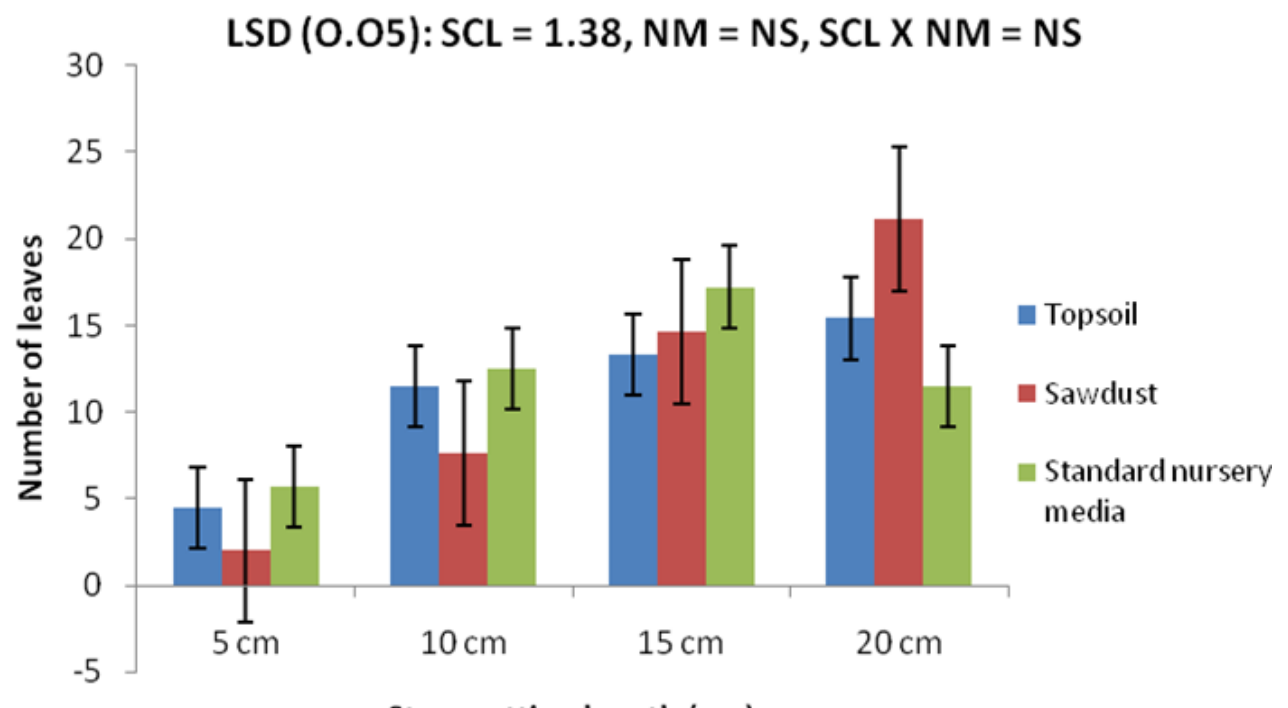

Stem cutting length $(\mathrm{cm})$

Figure 3. Effect of stem cutting length and nursery media on number of leaves at 1 MAS. Note: $\mathrm{SCL}=$ Stem cutting length, $\mathrm{NM}=$ Nursery media, $\mathrm{NS}=$ Non significant

\subsubsection{Shoot Height}

Shoot height was significantly $(\mathrm{p} \leq 0.05)$ affected by stem cutting length (Figure 4). Stem cutting length of 20 $\mathrm{cm}$ produced tall shoot $(5.26 \mathrm{~cm})$, followed stem cutting of by $10 \mathrm{~cm}$ length $(4.47 \mathrm{~cm})$ while stem cutting of $5 \mathrm{~cm}$ length produced dwarf shoot $(2.69 \mathrm{~cm})$. On mean value basis, tall shoot was produced by topsoil $(4.78 \mathrm{~cm})$ while sawdust produced dwarf shoots $(3.67 \mathrm{~cm})$. Stem cutting of $20 \mathrm{~cm}$ length raised in sawdust $(6.13 \mathrm{~cm})$ produced tall shoot while stem cutting of $5 \mathrm{~cm}$ length raised in sawdust produce dwarf shoot $(1.50 \mathrm{~cm})$. 


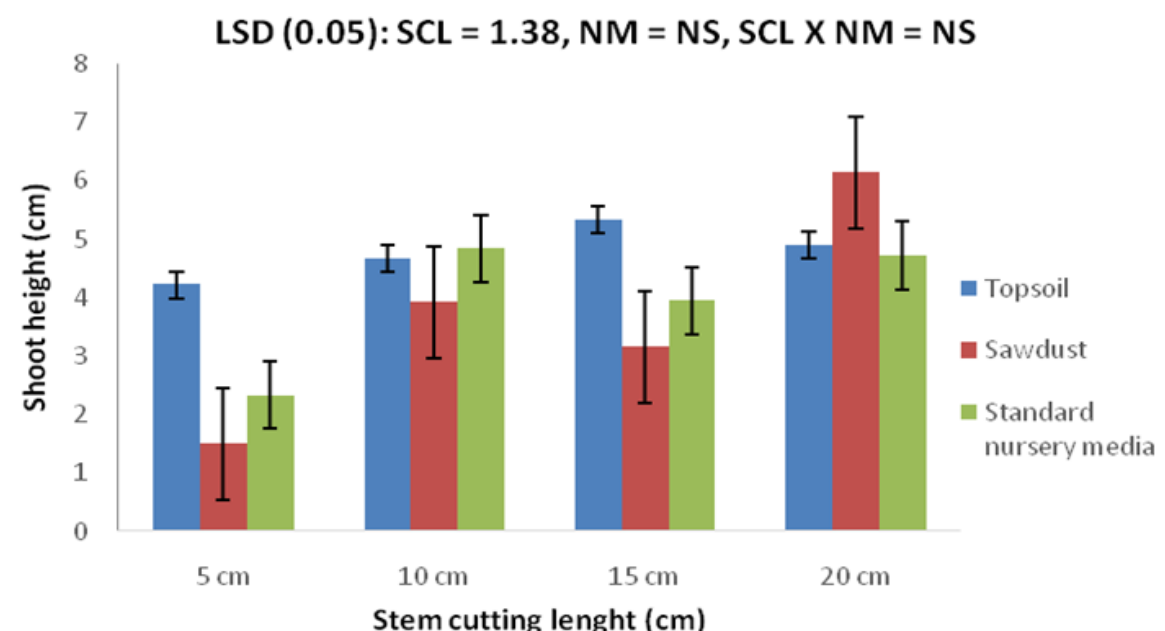

Figure 4. Effect of stem cutting length and nursery media on shoot height $(\mathrm{cm})$ at 1 MAS. Note: $\mathrm{SCL}=$ Stem cutting length, $\mathrm{NM}=$ Nursery media, NS $=$ Non significant.

\subsection{Experiment Two: Effect of Hours of Priming of Pterocarpus Mildbraedii Stem Cutting in Coconut Water}

Days to first sprouting was not significantly $(\mathrm{p} \leq 0.05)$ affected by hours of priming in coconut water $($ Table 2$)$. On mean value basis, Pterocarpus mildbraedii stem cutting primed for 48 hours sprouted earliest (7.67 days) while stem cuttings primed for 12 hours (14.67 days) and control sprouted late (14.67 days).

Days to $50 \%$ sprouting was not significantly affected by hours of priming in coconut water Table 2 . On mean value basis, stem cutting primed in coconut water for 24 hours achieved $50 \%$ sprouting in 12.00 days while stem cutting primed for 36 hours in coconut water had $50 \%$ sprouting within 24.30 days.

Pterocarpus mildbraedii shoot height was not significantly affected by hours of priming in coconut water Table 2. On mean value basis, tall shoot $(16.40 \mathrm{~cm})$ was produced by stem cutting primed in coconut water for 24 hours while dwarf shoot $(5.50 \mathrm{~cm})$ was produced by control.

Number of leaves was not significantly affected by hours of priming in coconut water Table 2. On mean value basis, priming in coconut water for 24 hours produced highest number of leaves (2.00) while control produced smallest number of leaves (9.60).

Estimated leaf area was not significantly affected by hours of priming in coconut water Table 2. On mean value basis, stem cutting primed in coconut water for 36 hours produced broad leaf $\left(19.50 \mathrm{~cm}^{2}\right)$ while stem cutting primed in coconut water for 48 hours produced narrow leaf $\left(9.70 \mathrm{~cm}^{2}\right)$.

Stem girth was significantly $(\mathrm{p} \leq 0.05)$ affected by hours of priming in coconut water Table 2. Stem cutting primed in coconut water for 24 hours produced biggest stem girth $(1.77 \mathrm{~cm})$ while control produced smallest stem girth $(0.63 \mathrm{~cm})$. There was no significant difference among stem girths produced by stem cuttings primed in coconut water for 12 hours $(0.89 \mathrm{~cm}), 36$ hours $(0.99 \mathrm{~cm})$ and 48 hours $(0.93 \mathrm{~cm})$. Number of roots was not significantly affected by hours of priming in coconut water Table 2. On mean value basis, stem cutting primed for 36 hours in coconut water produced highest number of roots (21.40) while control did not produce root (0.00). Root length was significantly affected by hours of priming in coconut water Table 2. Stem cutting primed for 12 hours in coconut water produced highest number of roots $(9.43 \mathrm{~cm})$ while control did not have root $(0.00 \mathrm{~cm})$. There was no significant difference among stem cuttings primed in coconut water for 12 hours $(9.43 \mathrm{~cm}), 24 \mathrm{hours}$ $(9.00 \mathrm{~cm})$ and 36 hours $(8.67 \mathrm{~cm})$. 
Table 2. Effect of hours of priming in coconut water on days to $1^{\text {st }}$ sprouting, days to $50 \%$ sprouting, sprout height, number of leaves, estimated leaf area, girth, number of roots, root length and fresh biomass of Pterocarpus mildbraedii at 1 MAs.

\begin{tabular}{|c|c|c|c|c|c|c|c|c|c|}
\hline Treatments & $\begin{array}{c}\text { Days to } \\
1^{\text {st }} \\
\text { sprouting }\end{array}$ & $\begin{array}{c}\text { Days to } \\
50 \% \\
\text { sprouting }\end{array}$ & $\begin{array}{l}\text { Shoot height } \\
(\mathrm{cm})\end{array}$ & $\begin{array}{c}\text { Number } \\
\text { of } \\
\text { leaves }\end{array}$ & $\begin{array}{l}\text { Estimated } \\
\text { Leaf area } \\
\quad\left(\mathrm{cm}^{2}\right)\end{array}$ & Girth $(\mathbf{c m})$ & $\begin{array}{l}\text { Number of } \\
\text { roots }\end{array}$ & $\begin{array}{l}\text { Length of } \\
\text { roots }(\mathrm{cm})\end{array}$ & $\begin{array}{c}\text { Fresh } \\
\text { biomass }(\mathrm{g} \\
\left.\text { plant }^{-1}\right)\end{array}$ \\
\hline Control & 14.67 & 14.70 & 5.50 & 9.60 & 16.70 & 0.63 & 0.00 & 0.00 & 3.02 \\
\hline 12 hours in coconut water & 14.67 & 22.70 & 4.90 & 11.60 & 12.10 & 0.89 & 15.30 & 9.43 & 4.86 \\
\hline 24 hours in coconut water & 9.30 & 12.00 & 16.40 & 27.00 & 16.90 & 1.77 & 12.00 & 9.00 & 11.55 \\
\hline 36 hours in coconut water & 11.33 & 24.30 & 10.40 & 17.50 & 19.50 & 0.99 & 21.40 & 8.67 & 8.32 \\
\hline 48 hours in coconut water & 7.67 & 13.30 & 8.30 & 14.30 & 9.70 & 0.93 & 12.00 & 4.17 & 4.57 \\
\hline $\operatorname{LSD}_{(0.05)}$ & 5.72 & 20.12 & 9.93 & 14.52 & 19.18 & 0.51 & 14.39 & 2.06 & 3.61 \\
\hline F-test & $\mathrm{NS}$ & NS & $\mathrm{NS}$ & NS & NS & ** & $\mathrm{NS}$ & *** & *** \\
\hline
\end{tabular}

Note: $\mathrm{LSD}_{(0,05)}=$ Least Significant Difference, ${ }^{*} *$ Significance at $1 \%$ level of probability. 
Fresh biomass was significantly affected by hours of priming in coconut water Table 2. Stem cutting primed in coconut water for 24 hours produced highest fresh biomass (11.55 g) while control produced least fresh biomass $(3.02 \mathrm{~g})$. There was no significant difference between fresh biomass of stem cutting primed in coconut water for 24 hours $(11.55 \mathrm{~g})$ and 36 hours $(8.32 \mathrm{~g})$. There was no significant difference between fresh biomass of stem cutting primed in coconut water for 12 hours $(4.86 \mathrm{~g})$ and 48 hours $(4.57 \mathrm{~g})$.

\section{DISCUSSION AND CONCLUSION}

4.1. Experiment One: Effect of Stem Cutting Length and Nursery Media on Sprouting and Growth of Pterocarpus Mildbraedii

Nursery media did not significantly affect the growth of Pterocarpus mildbraedii shoot. The cuttings only benefitted by imbibing moisture from the different media which triggered shoot emergence. Stem cuttings are known to absorb moisture in the absence of roots, and depend on the stored food reserve in the stem cutting for growth and wilting occurrs in the young shoots once the food reserves exhaust. This agrees with the work of Malamy [17] who reported that root system architecture is dependent on the composition of soil and the availability of nutrients. Inability of Pterocarpus mildbraedii to root in any of the media used could be related to the physical property of the media. The media used for the experiment did not have high water holding capacity and thus, there was not enough moisture retained in the media to induce rooting in the shoots. Ali and El-Tigani [18] reported that the ability of stem cuttings to root is dependent of positons of the shoots on the cutting, rooting media, and seasons when cutting was made. Relf and Ball [19] also confirmed that rooting in plants is dependent on rooting medium. Ngwuli, et al. [20] reported that Pterocarpus mildbraedii stem cutting showed higher growth and root performance in clay soil than in loamy soil because of the natural ability of clay soil to retain water. All the media used (topsoil, standard nursery media and sawdust) for this experiment did not have very high water retention capacity like clay as reported by Ngwuli, et al. [20] and thus could not have influenced rooting. Failure of the shoots to initiate and develop roots caused wilting one month after sprouting since the young shoots have exhausted the food reserves.

Stem cutting length determines the number of nodes contained within a given stem length and the number of nodes influences the number of shoots to be developed. Stem cutting length of $20 \mathrm{~cm}$ produced highest number of shoots and vigorous shoot growth in relation to other stem cutting lengths. This agrees with the work of Okunlola [21] who reported good growth and rooting in Duranta repens using $20 \mathrm{~cm}$ stem cutting length.

\subsection{Experiment Two: Effect of Hours of Priming of Pterocarpus Mildbraedii Stem Cutting in Coconut Water}

Priming of Pterocarpus mildbraedii stem cutting in coconut water induced rooting and vigorous shoot growth in relation to control. Pterpcarpus mildbraedii stem cutting is a hard wood and thus, takes a longer time to imbibe coconut water. Imbibition of coconut water for 24 hours was enough to activate sprouting and induce rooting in stem cutting primed. Stem cuttings primed irrespective of hours of priming produce roots and vigorous growth parameter in terms of shoot height, number of leaves and girth as well as fresh biomass. The observed higher differences in the growth and root development of stem cuttings primed before planting than in the conntrol could be that priming in coconut water helped in moisture retention, imbibitions and enzyme activities in the stem cutting. Also, coconut water is a source of growth hormone which induced rooting in the stem cutting. This is similar to the report of Ngwuli, et al. [20] and Nwoboshi [22] who reported that higher performance of Tetrapleura tetraptera in clay soil than in loamy soil could be as a result of the fact that clay soil retains more water than the topsoil and as such promoted enzyme activities and physiological activities during plant growth and development. 
Coconut water is a natural source of growth hormone that stimulated growth and root development in Christmas tree palm [23, 24]. Several authors have reported the successful use of coconut water and chemical hormones individually to induce rooting and growth in stem cuttings of tree crops [9, 25-28].

\section{CONCLUSION}

The first experiment failed because there was no root developed in the stem cuttings which resulted to wilting of Pterocarpus mildbraedii shoots one month after sprouting. However, priming of the stem cuttings for different hours in coconut water, shoots resulted in the development of roots at one month after sprouting. Rooting encouraged vigorous shoot growth in terms of number of leaves and shoot height when compared to the growth parameters of the shoots in the first experiment. Therefore, for propagation and domestication of Pterocarpus mildbraedii, stem cutting of $20 \mathrm{~cm}$ length should be primed in coconut water for 24 hours for improved rooting, shoot growth and development.

\section{REFERENCES}

[1] B. N. Okigbo, "Neglected plants of horticultural importance in traditional farming systems of tropical Africa," Acta Horticulturae, vol. 53, pp. 131 - 150, 1977.Available at: https://doi.org/10.17660/actahortic.1977.53.18.

[2] J. C. Okafor, "Improving edible species of forest products," Unasylva, vol. 165, pp. 17-23, 1991.

[3] I. Ibeawuchi, N. Okoli, R. Alagba, M. Ofor, L. Emma-Okafor, C. Peter-Onoh, and J. Obiefuna, "Fruit and vegetable crop production in Nigeria: The gains, challenges and the way forward," Journal of Biology, Agriculture and Healthcare, vol. 5, pp. 194-208, 2015.

[4] O. Ndukwe and A. Ikpeama, "Comparative evaluation of the phytochemical and proximate constituents of Oha (Pterocarpus soyansii) and nturukpa (Pterocarpus santalinoides) leaves," International Journal for Academic Research in Progressive Education and Development, vol. 2, pp. 22-31, 2013.Available at: https://doi.org/10.6007/ijarped/v2-i3/22.

[5] B. A. Adeleja and I. O. Fasidi, "Survey and collection of indigenous piece of germplasm for conservation and genetic improvement in Nigeria biodiversity," International- FAO Published Issue, vol. 153, pp. 67 - 74, 2008.

[6] N. Okoli, J. Obiefula, A. Obasi, I. Ibeawuchi, G. Ihejirika, R. Alagba, and C. Peter-Onoh, "Nursery Techniques for the propagation of Pterocarpus mildbraedii Harms (Oha ojii) in Owerri West, Southeastern, Nigeria," FUTO Journal Series, vol. 1, pp. 91-95, 2015.

[7] M. Adebisi, T. Kehinde, A. Esuruoso, M. Ajala, O. Oni, and K. Ajagbe, "Improvement of seed germination and seedling vigour of garden egg (Solanum melongena) genotypes using hydro priming and dehydration treatments," Journal of Organic Agriculture and Environment, vol. 1, pp. 29-35, 2013.

[8] G. E. Omokhua, H. I. Aigbe, and N. B. Ndulue, "Effects of pre germination treatments on the germination and early seedling growth of Tetrapleura Tetraptera (Schum. \& Thonn.)," International Journal of Scientific and Technology Research, vol. 4, pp. $160-165,2015$.

[9] I. Usman and A. Akinyele, "Effects of growth media and hormones on the sprouting and rooting ability of Massularia acuminate (G. Don) Bullock ex Hoyl," Journal of Research in Forestry, Wildlife and Environment, vol. 7, pp. 137-146, 2015.

[10] J. W. Yong, L. Ge, Y. F. Ng, and S. N. Tan, "The chemical composition and biological properties of coconut (Cocos nucifera L.) water," Molecules, vol. 14, pp. 5144-5164, 2009.Available at: https://doi.org/10.3390/molecules 14125144.

[11] W. H. Hendershot, H. Lalande, and M. Duquette, Soil reaction and exchangeable acidity, soil sampling and methods of analysis, M. R. Carter ed. London: Canadian Society of Soil Science, Lewis Publishers, 1993. 
[12] D. Nelson and L. E. Sommers, "Total carbon, organic carbon, and organic matter," Methods of Soil Analysis: Part 2 Chemical and Microbiological Properties, vol. 9, pp. 539-579, 1983.

[13] S. R. Olsen and L. E. Sommers, "Phosphorus. In: Paige, A. L, Millers, R. H. And Keeney, R. R. (Eds.), Methods of soil analysis," ed Madison, WI: American Society of Agronomy, 1990, pp. 403 - 430.

[14] FAO, "Standard operating procedure for soil nitrogen- Kjeldahl method," ed Rome: Global Soil Laboratory Network (GLOSOLAN), 2021 , pp. 1-25.

[15] G. H. Bouyoucos, "A recalibration of the hydrometer for making mechanical analysis of soils," Agronomy Journal, vol. 43, pp. 434-438, 1951.Available at: https://doi.org/10.2134/agronj1951.00021962004300090005x.

[16] Genstat, "Genstat for windows, discovery," 3rd ed UK: Lawes Agricultural Trust, Rothamsted Experimental Station, 2007 , p. 147.

[17] J. Malamy, "Intrinsic and environmental response pathways that regulate root system architecture," Plant, Cell $\mathcal{E}^{\circ}$ Environment, vol. 28, pp. 67-77, 2005.Available at: https://doi.org/10.1111/j.1365-3040.2005.01306.x.

[18] Y. Ali and S. El-Tigani, "Vegetative propagation of Acacia senegal (willd.) By stem cuttings," Sudan Silva, vol. 9, pp. 36-45, 2003.

[19] D. Relf and E. Ball, "Propagations by cuttings, layering and division. Virginia cooperative extension," Virginia Polytechnic Institute and State University, vol. 426, pp. 1-6, 2009.

[20] C. Ngwuli, R. Mbakwe, and A. Uwaga, "Effect of different soil types and season on the vegetative propagation of Pterocarpus species in the humid tropic of South Eastern Nigeria," Journal of Research in Forestry, Wildlife and Environment, vol. 11, pp. 107-118, 2019.

[21] A. I. Okunlola, "The effects of cutting types and length on rooting of Duranta Repens in the nursery," Global Journal of Human Social Science, vol. 13, pp. 1-5, 2013.

[22] L. C. Nwoboshi, The nutrient factor in sustainable forestry. Ibadan: Ibadan University Press, 2000.

[23] T. Umi and W. Siti, "The effect of coconut water and planting media to the growth of christmas palm (Veitchia merilli)," Advances in Social Science, Education and Humanities Research, vol. 429, pp. 79 - 82, 2020.

[24] S. F. Sujarwati and E. H. Johani, "Use of coconut water to increase germination and growth of Christmas palm," Sago Journal, vol. 10, pp. 24-28, 2011.

[25] S. A. Sumbele, "Effects of auxins and leaf size on rooting of Treculia africana (Decne) Stem cuttings," Science Journal of Environmental Engineering Research, 2012.

[26] R. Tiwari and K. Das, "Effect of stem cuttings and hormonal pre-treatment on propagation of Embelia tsjeriam and Caesalpinia bonduc, two important medicinal plant species," Journal of Medicinal Plants Research, vol. 4, pp. 1577-1583, 2010.

[27] U. L. Undie and O. Agba, "Effects of coconut (Cocos Nucifera L.) drupe water and cotyledon wounding on seed germination and seedling performance in Kola Nuts (Cola Spp.)," International Journal of Agriculture and Earth Science, vol. 4, pp. 24-29, 2018.

[28] S. J. Singh and T. U. Maheswari, "Influence of pre-sowing seed treatments on the performance of soursop (Annona muricata L.) seedlings," Plant Archives, vol. 17, pp. 1215-1218, 2017.

Online Science Publishing is not responsible or answerable for any loss, damage or liability, etc. caused in relation to/arising out of the use of the content. Any queries should be directed to the corresponding author of the article. 